\title{
Perception and Press in Revolutionary Transylvania. 1848-1849
}

\section{Cătălin Chebuţ}

Tirgu Mures Univesity, Romania

kebootz@yahoo.com

\section{Doi:10.5901/ajis.2013.v2n2p443}

\begin{abstract}
:
The perception of the "Other" has always been a lingering matter in the minds of those who shared, through historical ethnic distribution, the same territory. In the case of Transylvania, given its multicultural setting, these types of perceptions were essentially the result of a long history of cohabitation, which was at times severely affected by politically-generated conflicts such as revolutions and the auxiliary fronts that supported their cause, like the press.
\end{abstract}

Keywords: Press, Alterity, Transylvania, Conflict, 1848, Revolution

\section{Introduction}

The multicultural realm of Transylvania is nowadays a part of Romania, a reality that remained largely unscathed during the course of the past century. Nevertheless, retrospectively seeing and politically speaking, barely a hundred years ago things were quite different mainly due to the nature of the epoch's geopolitical context and the fact that it belonged to the neighboring kingdom of Hungary, which constituted the Transleithanian part of the Austro-Hungarian Empire. In the course of its known history however, authority shifts such as these have always been a fairly common occurrence. For the majority of its inhabitants, namely Romanians and Hungarians, irrespective of the power holding authority over it, it was and still is a land by which they identify with, calling it home and viewing it primarily as a historical hearth of cultural development, an issue which led over the course of time to unfortunate and fierce demonstrations of patriotism fueled mainly by the political elites. Such was the case of the sorrowful events of the fiery years 1848 and 1849 .

The Hungarian Revolution of 1848-1849, like the other unprecedented national movements spread throughout Europe at the time, was aimed primarily at establishing a new political order by crushing absolutism and severing its tentacles. In this case, it was a two-sided conflict with and within the Austrian Empire. For historiography, especially the Romanian one, this chain of events is a thorny issue that has to be studied thoroughly in order to explain its numerous important aspects. Therefore, writing a study with the foreseeable goal of analyzing a historical phenomenon in a given context, requires, first and foremost, the crossing of a bookish passageway sprinkled with bits of philosophy, psychology, sociology, anthropology, statistics and linguistics, that eventually leads to the realm of historical writing, which is more or less interpretative and/or descriptive in nature. Hence, such an enterprise is qualitatively and quantitatively speaking consistent and complicated, given the fact that is a scientific work and certainly not a quizzical tabloid regarding the past. In this respect, I am enthralled by the idea of exposing some of the framework of this historical event by bringing into discussion the role played by the press in creating, influencing or fueling images, stereotypes and perceptions in the minds of the Hungarian revolutionary elites, which in turn had a huge impact on the opinion of Hungarian commoners. After all, they perceived the Romanian response as a threat, which led the press to turn its attention to an issue which was, until then, rarely discussed. The "Transylvanian-Romanian Alterity".

\section{1848-1849. Conflict and perceptions}

Being seen and described as meek and peaceful, with the majority living in a harsh, economic backwardness, the Transylvanian Romanians rarely presented a point of interest for the Hungarian political elites and the press. As the Romanian poet and journalist Octavian Goga said: "Ca pe un popor de ţărani ne-a ajuns anul de sguduire: patruzeci şi 
opt", which can be poetically translated as "The year 1848 hit us with modernity's sledgehammer while we were still wearing traditional peasant garments" (Adevărul, Tara Noastră, II [1908], no. 21, p. 1).

Kossuth Lajos for example, the leader of the Revolution, did not even know about the Romanian militancy before 1848, seeing them as part of a small and non-historical people, given the fact that unlike Hungarians and Croatians, they lacked the tradition of statehood. As pointed out by historian Melinda Mitu, "The Hungarian politician and statesman played an important role in the crystallization of the liberal opposition. Yet, despite de fact that he published a great number of articles devoted to nation and nationalities, his references to Romanians are extremely rare[...] Like his branch-brothers, his main interests were the Germans and the Slavic peoples of Hungary" (Cluj-Napoca: Presa Universitară Clujeană, 2000, p. 274).

Nevertheless, the large number of Romanians living in Transylvania made it impossible for other journalists to ignore them, especially when their main point of interest focused on the problems of nationalities. Such was the case, for example, of a certain individual working for Pesti Hírlap and which signed articles under the name A.B. Concerned, like many others, about the above-mentioned issue, he confidently declared in 1842 that "The Romanians, the largest national group in our country after the Slavs, are a race that had beautiful historical moments. They live from Bucovina to the borders of Turkey, in all the eastern part of our country, and in every county and district of Transylvania, with the exception of the lands inhabited by the Székely people" (apud Melinda Mitu, Cluj-Napoca: Presa Universitară Clujeană, 2000 , p. 283). Other journalists, like Somogy Antal and Jakab Elek made good use of such descriptions in the years before the revolution, when they sincerely pleaded for the emancipation of all nationalities, including Romanians. In this respect, such was the impact of their efforts that George Bariţiu, a Romanian key figure in the revolution, noted that "Niciodată condei de român n-a putut scrie cu interes mai mare, nici nu a putut zugrăvi ticăloşia şi toate năpăstuirile românilor cu vioiciune mai multă decât Erdélyi Hirradó astă dată" (Melinda Mitu, op. cit., p. 293), which could be summarized as "Erdélyi Hiradó illustrated all the shortcomings of the Transylvanian Romanians more successfully than any Romanian journalist ever did".

However, as the Revolution was drawing near, slowly but surely, more and more publications were beginning to acknowledge and take into account certain issues pertaining to the Transylvanian Romanians and their status. As pointed out earlier, Pesti Hírlap, Erdélyi Híradó or Márczius tizenötödike were some of the most important.

The beginning of this nationalistic uprising and especially the summer of 1848 was, in this respect, the launch pad for countless articles forged and fueled essentially by the spirit of this new-born revolutionary idea, many of which made reference to recurrent themes such as the issue of nationality and the preservation of the Hungarian fighting spirit. Therefore, even if the political press covered a wide array of subjects before, its main objective during the revolution was shaped by the will of its leaders, who used it for broadcasting information, requests, demands and orders, which were more or less focused on the moment's necessities and which in turn led to the unforeseen aspect of shaping and subsequently transforming, through the means of this politically-directed machinery, the image of the perceived "enemy" into a monolithic whole. In other words, a process of negative mass-labeling of those who partly or totally disagreed with the ideas of the revolution took place. Thus, the leading principle of the revolution seemed to be: "Si vis pacem, para bellum et scriptum", given the fact that blood and ink were flowing like two inseparable streams and as 1848 was drawing to an end, the "volumetric flow rate" of both increased to that of rivers.

Eric Hobsbawn, in his influential book "Nations and Nationalism since 1780: programme, myth, reality" asserted that, historically speaking, nationalism forged nations and not the other way around (Central European University Press, 1996, p. 12). If we were to put this on display alongside the anxieties of certain Hungarian revolutionary leaders regarding the success of their cause, we can see that their main point of interest and ultimately fear was that in the midst of so many problems, the nationalities would somehow manage to create and subsequently maintain their own states. In Transylvania, the situation was deemed even more dangerous by the Kossuth and the revolutionary cabinet, given the fact that a great number of Romanians lived there in large clusters, which could turn, at any given time, into exploding gun powder kegs, a thing that eventually happened.

The Romanians of Transylvania, more scared and less prepared, responded as some of the Hungarian revolutionary leaders may have expected, by seeking protection. As historian Gelu Neamţu pointed out, "many Romanians, in need of security, instinctively headed towards the two Romanian frontier guards regiments based at Năsăud/Naszód and Orlat/Orlát (Cluj-Napoca: Editura George Bariţiu, 1997, p. 851). However, the responses which sadly and greatly contributed to the distortion of perception among the Hungarian revolutionaries regarding Romanians were, as I above mentioned, related to gun powder kegs, as well as cannons, rifles and muskets and all the fighting, violence 
and resistance that ensued and characterized both sides. Briefly described, it was an episode of conflict and politicallygenerated imagery.

On the other hand, there were certain publications interested in the way things were developing in Transylvania in the revolutionary context and which were less politically-oriented or rather not affiliated to the Hungarian cause. Such was the case, for example, of Allgemeine Zeitung, who made frequent references to the Romanians, many of which were positive and supportive in nature. In the words of historian Grigore Ploeşteanu: "Allgemeine Zeitung published in 18481849 numerous articles which made, among others, clear reference to Romanians and their national movement.[...] Through the medium of this famous German newspaper, the Transylvanian Romanian Issue was made public on an European level" (Târgu-Mureş: Editura Veritas, 2010). However, as the scope of this article does not include the analysis of publications who weren't politically involved in supporting the Hungarian Revolution, a more detailed description will not follow. I chose however, to briefly mention the existence of a different point of view pertaining to the Revolution to show that the political and cultural environment in which an idea or image is born is primarily responsible for it shape, size, content and quality.

\section{Conclusions}

The year 1849 marked the end of this revolutionary struggle. The intervention of the Russian armed forces compelled the Hungarians to sue for peace at Világos, a thing that, for Austria alone, it was nigh impossible to achieve. Many journalists viewed it as a stinging defeat for their guild also, having a sense of helplessness because they weren't able to muster enough support for their cause, which in turn could have been favorable to the success of the revolution.

In my opinion, a conflict can be defined as a failed intercultural dialog. In this matter, whether or not one party accepts the arguments of the opposing party, the "discussion" itself puts both of them face to face, thus contributing to the process of familiarization. The Hungarian Revolution of 1848-1849 did exactly that, dramatically allowing the revolutionary leaders to become acquainted with the "Other", which was in this case, the Romanians of Transylvania. Obviously, the press played a major part in this epoch-making "discussion", given the fact that it conveyed, through its articles, not only plain information, but fiery perception-shaping emotions worthy of contemporary propaganda. Ultimately, the Revolution was directed at demolishing a "crumbling" empire which suffocated nationalities, and this specific aspect could give us an insight of why some of the Hungarian leaders and journalists were wary of Romanians, while others simply wanted to see them as allies, because in the end, the enemy of my enemy is my friend. History however took another course.

A catalyst of public opinion yet tributary to the fluctuation of events and ideology, the press made in 1848 and 1849 a clear demonstration of how strongly it could influence emotions and perceptions on both sides of a conflict. Even though the high rate of illiteracy made it impossible for the masses to read it and get an idea of how the big picture looked like, the revolutionary leaders, aware of its potential, successfully used it as a propaganda tool. The press, therefore, had a huge perception-shaping impact in an epoch when people read more and before the radio, the television and the internet brought them closer than ever.

\section{References}

Beller M. - Leerssen J., Imagology: The cultural construction and literary representation of national characters, Amsterdam: Editions Rodopi B.V., 2007

Bocşan N. et al., Identitate şi alteritate, Cluj-Napoca: Presa Universitară Clujeană, 1998

Chiciudean, Ion, Imagologie. Imagologie istorică, Bucureşti: Editura Comunicare.ro, 2003)

Hobsbawn E., Nations and Nationalism since 1780: programme, myth, reality, Budapest: Central European University, 1996

Mazilu D.H., Noi despre ceilalţi. Fals tratat de imagologie, Iaşi: Polirom, 1999

Maior L., 1848-1849: Români şi unguri în revoluţie, Bucharest: Editura Enciclopedică, 1998

Mitu M., Problema românească reflectată în cultura maghiară din prima jumătate a secolului al XIX-lea, Cluj-Napoca: Presa Universitară Clujeană, 2000

Neamţu G., Istoria României. Transilvania, vol I., Cluj-Napoca: Editura George Bariţiu, 1997

Ploeşteanu G., Românii în conştiinţa Europei, Târgu-Mureş: Editura Veritas, 2010

Wolff L., Inventarea Europei de Est. Harta civilizaţiei în epoca luminilor, Bucharest: Humanitas, 2000

Goga O., Adevărul, in Ţara Noastră, II (1908), no. 21 
